\title{
Functional Food for Dogs and Cats: Nutrients that Help Improve Pet Health
}

\author{
Julio Bernal* \\ GEPSA Pet Food Technical Department, Argentina \\ *Corresponding Author: Julio Bernal, GEPSA Pet Food Technical Department, \\ Argentina.
}

DOI: $10.31080 /$ ASNH.2020.04.0627
Received: January 09, 2020

Published: January 28, 2020

(C) All rights are reserved by Julio Bernal.
Driven by the growing interest in improving the health and well-being of dogs and cats through diet, the so-called functional foods occupy an increasingly prominent place in the nutrition of these animals.

Although initially the advances in the knowledge about this type of food were directed only towards human nutrition, at present several pet food brands, in particular those of Premium and Super Premium quality, also contribute in their formulas some of these healthy nutrients.

The concept of functional food originated in Japan at the beginning of the 1980s. At that time the Japanese government, concerned about the rise in its expenses in Public Health as a result of the increase in the life expectancy of its population, initiated a series of nutritional research programs. Its purpose was to obtain food that would provide the necessary nutrients to "avoid deficiencies and improve the quality of life of its inhabitants". As a result of these studies, they established a new category of potentially beneficial foods, called "functional foods" or "foods for specific health use" (FOSHU).

\section{Hippocrates already said it}

Beyond the Japanese history, the relationship between good nutrition and good health has been known for about 25 centuries ago, when the Greek Hippocrates of Cos, the father of modern Medicine, already recommended: "Let your food be your medicine, and may your medicine be your food".

This healthy conception of nutritional management, renamed in 1989 as nutraceutical by Dr. Stephen DeFelice, also began to be applied in the formulation of balanced feed for dogs and cats. In large part, it emerged in response to the growing demand of some pets parents who already incorporated functional nutrients into their diets and who, when choosing a balanced food for their pets, began to look for pet food brands that would also provide them in its composition.

In addition to this trend, the advance in scientific knowledge about certain healthy properties of some natural ingredients led to the emergence of new claims to communicate the benefits for the welfare of pets linked to the consumption of this type of food. In this sense, it became increasingly common to find petfoods that, thanks to the inclusion of functional ingredients, "favor intestinal health", "stimulate or strengthen the immune system", "decrease inflammatory processes" and even "improve development neuronal" (see table 1).

\section{Nutrition-health}

The functional nutrients help keep dogs and cats healthy through different mechanisms of action that act at different levels of the body.

Some have the property of helping to neutralize the harmful action, caused by cells called free radicals, chemical substances that are generated as a result of cellular metabolism reactions (oxidation). Some of the antioxidant functional nutrients that protect the body from pets are: tomatoes, which provide lycopene; Marigold's blueberries and flowers, which contain flavonoids; green tea, grapes and apples, with polyphenols; Rosemary extract, which has carotenoids, among others.

The so-called functional fibers, or prebiotics, favor the selective development of the "beneficial" microorganisms of the intestinal microbiome. In this way they contribute to strengthen intestinal health. Among the functional nutrients that provide them can be mentioned beet pulp, chicory and fructooligosaccharides, among others. Under the term probiotic (in favor of life), FAO defines "living microorganisms that exert a beneficial action on host health when administered in adequate amounts". The incorporation of Lactobacillus and bifidobacteria in the formula of some pet foods contributes to improve intestinal health, strengthen the immune system and stimulate the proper functioning of the gut-brain axis.

The contribution in the pets diets of DHA (docosahexaenoic acid), a fatty acid from the omega 3 family, helps strengthen the development of the central nervous system and neural functioning in puppies. At the same time, it helps increase the post-vaccination response in puppies due to the generation of higher concentration of antibodies [1-6]. 


\begin{tabular}{|c|c|c|}
\hline Ingredient & Functional nutrient provided & Health benefits \\
\hline $\begin{array}{l}\text { Fish oil } \\
\text { Marine microalgae } \\
\text { Chia seeds }\end{array}$ & $\begin{array}{c}\text { Essential fatty acids } \\
\text { omegas } 3 \text { (DHA/EPA) }\end{array}$ & $\begin{array}{c}\text { Contribute to ... } \\
\text { Reduce inflammatory processes. } \\
\text { Improve neuronal development in puppies. } \\
\text { Improve vision (contrast discrimination ability) } \\
\text { Improve the response in learning tests in puppies. } \\
\text { Improve early psychomotor performance (puppies). } \\
\text { Improve the post-vaccination response. }\end{array}$ \\
\hline $\begin{array}{l}\text { Prebiotic fibers: } \\
\text { Beet pulp } \\
\text { Chicory }\end{array}$ & $\begin{array}{c}\text { Fructooligosaccharides (FOS) } \\
\text { Inulin }\end{array}$ & $\begin{array}{l}\text { Contribute to ... } \\
\text { Improve intestinal health. } \\
\text { Promote the gut-brain axis. }\end{array}$ \\
\hline Probiotic microorganisms & Lactobacillus/bifidobacterias & $\begin{array}{l}\text { Contribute to... } \\
\text { Improve intestinal health. } \\
\text { Stimulate the immune system. } \\
\text { Favoring the gut-brain axis. }\end{array}$ \\
\hline Yeast wall & Mananooligosaccharides (MOS) & $\begin{array}{l}\text { Contribute to... } \\
\text { Protect the gut against pathogenic bacteria. }\end{array}$ \\
\hline $\begin{array}{l}\text { Cranberries/other red fruits } \\
\text { Calendula (Marigold) }\end{array}$ & Flavonoids (antioxidant) & \multirow{6}{*}{$\begin{array}{l}\text { Contribute to... } \\
\text { Protect cell membranes against free radicals. }\end{array}$} \\
\hline Tomato & Lycopene (antiox.) & \\
\hline $\begin{array}{l}\text { Green Tea } \\
\text { Grapes } \\
\text { Apple }\end{array}$ & $\begin{array}{l}\text { Polyphenols (catechins, antiox.) } \\
\text { Polyphenols (resveratrol, antiox.) } \\
\text { Polyphenols (quercitin, antiox.) }\end{array}$ & \\
\hline $\begin{array}{l}\text { Rosemary Extract } \\
\text { Beef/poultry/fish } \\
\text { Fruits/vegetables (carrot, etc.) }\end{array}$ & $\begin{array}{l}\text { Carotenoids (antiox.) } \\
\text { Vitamin A (antiox.) } \\
\text { Provitamin A }\end{array}$ & \\
\hline $\begin{array}{l}\text { Sunflower seeds } \\
\text { Vegetable oils (canola) }\end{array}$ & Vitamin E: tocopherols (antiox.) & \\
\hline $\begin{array}{l}\text { Kiwi (Actinidia deliciosa) } \\
\text { Red pepper }\end{array}$ & Vitamin C (antiox.) & \\
\hline Beer yeast & Betaglucans & $\begin{array}{l}\text { Contribute to... } \\
\text { Stimulate the immune system }\end{array}$ \\
\hline
\end{tabular}

Table 1: Main functional nutrients provided by pet foods.

\section{They prevent, they don't cure}

Although the consumption of balanced foods with functional nutrients helps to ensure the good health of dogs and cats, it is important to note that they do not have therapeutic properties. Nutraceuticals is a very useful help tool for the veterinarian in the preventive dietary management of certain pathologies of domestic pets. They do not replace but do contribute the conventional therapeutic methods used in the clinic of small animals.

\section{Bibliography}

1. Olagnero Gabriela., et al. "Functional foods: Concepts, Definitions and Global Legal Framework". DIAETA (B. Aires) 25 (2007): 119.
2. Steven C. Zicker, et al. "Evaluation of cognitive learning, memory, psychomotor, immunologic, and retinal functions in healthy puppies fed foods fortified with docosahexaenoic acid-rich fish oil from 8 to 52 weeks of age". Journal of the American Veterinary Medical Association 241 (2012): 583-594.

3. A Di Cerbo., et al. "Functional foods in pet nutrition: Focus on dogs and cats". Research in Veterinary Science 112 (2017): 161166.

4. A Di Cerbo., et al. "Functional Pet Foods" (2017). 
5. Brian S Beale., et al. "Nutraceutical treatment in dogs and cats". Proceeding of the NAVC North American Veterinary Conference (2005).

6. DeFelice Stephen. "The nutraceutical revolution: Its impact on food industry R\&D". Trends in Food Science and Technology 6 (1995): 59-61.

\section{Assets from publication with us}

- Prompt Acknowledgement after receiving the article

- Thorough Double blinded peer review

- Rapid Publication

- Issue of Publication Certificate

- High visibility of your Published work

Website: www.actascientific.com/

Submit Article: www.actascientific.com/submission.php

Email us: editor@actascientific.com

Contact us: +919182824667 